Man and Nature

L'homme et la nature

\title{
Legislating Virtue: John Brown's Scheme for National Education
}

\section{James E. Crimmins}

Volume 9, 1990

URI : https://id.erudit.org/iderudit/1012611ar

DOI : https://doi.org/10.7202/1012611ar

Aller au sommaire du numéro

Éditeur(s)

Canadian Society for Eighteenth-Century Studies / Société canadienne d'étude du dix-huitième siècle

ISSN

0824-3298 (imprimé)

1927-8810 (numérique)

Découvrir la revue

Citer cet article

Crimmins, J. E. (1990). Legislating Virtue: John Brown's Scheme for National Education. Man and Nature / L'homme et la nature, 9, 69-90.

https://doi.org/10.7202/1012611ar

Copyright (C Canadian Society for Eighteenth-Century Studies / Sociéte canadienne d'étude du dix-huitième siècle, 1990
Ce document est protégé par la loi sur le droit d'auteur. L'utilisation des services d'Érudit (y compris la reproduction) est assujettie à sa politique d'utilisation que vous pouvez consulter en ligne.

https://apropos.erudit.org/fr/usagers/politique-dutilisation/ 


\section{Legislating Virtue: John Brown's Scheme for National Education*}

John Brown (1715-66) was a figure well-known in his own day. He was a King's Chaplain, a member of Warburton's circle, an acquaintance of Dr. Johnson (who thought him quite mad), and friend and correspondent of David Garrick. ${ }^{1}$ More importantly, Brown was a prolific writer, publishing works of drama and poetry (including An Essay on Satire: Occasioned by the Death of Mr. Pope, which first brought him to the attention of Warburton in 1748), ${ }^{2}$ works on ethics, theology, politics, education, music and history. All received his attention in the indefatigable spirit of the eighteenth-century man of letters. His best work was done with the encouragement of Warburton relatively early in his career in the Essays on the Characteristics of the Earl of Shaftesbury (1751). ${ }^{3}$ Here one finds an impressive rendering of the doctrine of utility from the perspective of Christianity, praised, nearly one hundred years later, by no less a figure than J.S. Mill. ${ }^{4}$ Brown's most popular work, however, was the very successful tract An Estimate of the Manners and Principles of the Times, written when England seemed on the verge of a French defeat and published when public opinion was confused and volatile in 1757.

The Estimate provides a critical analysis of the moral condition of England, a bitter polemic against the unprincipled politics fostered by the Walpolean regime, and a range of loosely connected recommendations for ameliorating moral and political corruption. Here Brown enunciated the view that the ability of a state to survive and prosper is dependent on the predominant manners and principles of its leading ranks, and that the ruling characteristic of the times was that of profligate vice, 'a vain, luxurious and selfish EFFEMINACY. ${ }^{5}$ His purpose was to impress upon Englishmen of all persuasions that it was their lamentable lack of moral fibre, their preoccupation with commercial affairs, and their indifference to religious principles and practice that had brought them to the brink of defeat in the war against France. As denunciatory works in troubled times often do, the Estimate caught the popular imagination and six editions appeared before the year was out. ${ }^{6}$ By early 1758 , however, the tide of war had turned. 'Victory refuted all he said,' 
announced Cowper in the Table Talk. The stir caused by the Estimate was soon forgotten and Brown was never to regain the fleeting fame afforded him by his essay upon the depravity of the times. ${ }^{7}$ Horace Walpole set the seal on contemporary opinion with his customary aplomb. Brown, he wrote, was a 'mountebank, who for a little time made as much noise by his Estimate, as ever quack did by nostrum. ${ }^{8}$

Elsewhere I have discussed Brown's 'science of manners' and its political implications; ${ }^{9}$ here I am concerned with his thoughts on education. In education he professed to find the antidote to England's moral degeneration. With one or two exceptions, the last few years of his life were to be devoted to this subject. ${ }^{10}$ In a variety of polemical sermons and tracts, he argued that England's salvation was to be sought in a fundamental reformation of the national character, achieved through a combination of sound laws and a rigorous system of national education. He first gave attention to the matter in his three essays 'On the First Principles of Education' in 1762, in which he responded to Rousseau's prescriptions for individualist instruction in Emile. A year later he delivered two sermons 'On the Duty of Charitable Distribution,' rebutting Mandeville's attack on the charity schools. ${ }^{11}$ In 1765 Brown's Thoughts on Civil Liberty, On Licentiousness and Faction appeared, in which he renewed the moral-cum-political critique of the Estimate, adding that the essential prop to the durability of a state lay with correctly fashioned institutions, not the least of which should be a statesponsored scheme of education. The same year he published a brief sermon On the Female Character and Education pointing out the social benefits of female education. Finally, in a series of letters written shortly before his suicide in September 1766, he sketched out an exorbitant broad-ranging plan for a system of education designed for Catherine the Great's Russia. ${ }^{12}$ Brown's thoughts in these writings show him to be at the forefront of the European debate over the aims, content and form of education.

In Brown's day education in England was a combination of many disparate elements: in addition to the traditional practice of hiring private tutors, there was a great variety of charity schools, public schools, and schools run independently by individuals, corporations and denominations. With the possible exception of the universities, the state exercised no control over education. In the maelstrom of debate over this and other issues concerning education the ideas of John Locke played a conspicuous role. In his Essay concerning Human Understanding (1690) he portrayed the mind as a tabula rasa open and responsive to the 
stimuli provided by its social environment. Only one-tenth of a person's character was 'natural'; the remainder was the product of external influence. In Some Thoughts Concerning Education (1693) he set out a method of education in which the discipline of mind and body depended upon the formation of good habits. Here Locke drew upon Plutarch's De educatione puerorum, ${ }_{13}^{13}$ commenting that 'just as seals leave their impression in soft wax, so are lessons impressed upon the minds of children while they are young.' Character was simply 'habit long continued', and the 'virtues of character the virtues of habit ....' But Plutarch had also stipulated that virtue's 'first beginnings come from nature', hence for him habit was only a second nature. ${ }^{14}$ For Locke, however, as John Passmore has said, habit was 'a first nature. ${ }^{15}$ In this manner Locke established a psychological base from which to critically assess current educational practices and to develop new approaches.

Like so many others, Brown was an admirer of Locke's work and welcomed the unprecedented impetus it offered educational reform. Along with other disciples, he firmly held as true what the master had written: 'that, of all men we meet with, nine parts of ten are what they are, good or evil, useful or not, by their education. ${ }^{16}$ Given this edict, the eighteenth century turned its eyes to education just as Locke said it should - as the means to restore to the nation her former strengths and virtues. ${ }^{17}$ Upon the way this was to be achieved, however, opinion was divided. Some, admittedly a small number, believed that education could be improved only if relieved of the prejudices of religious doctrines; Anglicans and dissenters, though they disagreed on so many other things, maintained the contrary, that not enough attention was paid to religious principles. Some educationalists devoted themselves to a curriculum intended to produce the perfect English gentleman destined for high office; others turned their attentions to devising schemes for collective forms of education, both for the middling and the lower ranks. On the other hand, there were the critics who deplored the everwidening circle of education. Mandeville, for example, argued vigorously for closing the pioneering charity schools in order to leave the poor ignorant but industrious. Such attacks could not help but raise the ire of philanthropists, who held more closely to the principles of Christianity and promoted education for the poor, albeit of a rudimentary kind, as a basic charitable duty.

Brown found much to criticize in the contemporary practices. He complained of the universities and the public schools where the classics still dominated the curriculum. He believed with Comenius, Locke, John Clarke and other educationalists, that it was a basic defect that these institutions taught their pupils about 'words' but not about 'things. ${ }^{18}$ Like Locke and others too, Brown attacked the popular notion that 
schooling should be coupled with an exposure to the world and denounced those who would send England's youth on a premature 'grand tour' of Europe. This, he noted, was a recipe for acquiring foreign vices, not improving minds - a charge later echoed by Adam Smith. ${ }^{19}$ Before they are allowed to travel, Brown argued, 'the Taste and Habits of our rising Youth ought to be severely and unalterably formed. ${ }^{20}$ The most contentious of Brown's criticisms focused on the need for uniformity in England's schools. Only the direct involvement by government in education could establish uniformity, and this was an issue of some moment to educationalists throughout Europe by the middle of the eighteenth century.

In France the debate regarding the value of 'public' instruction began in 1746 when the Abbé Terrisse delivered a memoir before the Academy of Rouen entitled Examen de la question s'il est utile ou préjudiciable au bien de l'État que les gens de la Campagne sachent lire et écrire. ${ }^{21}$ The Abbé emphasized the evils of ignorance, the advantages to be derived from education, the inalienable right of all to instruction, and the religious benefits of public instruction, but it was the stress on the social utility of literacy that was new and forward-looking in the Examen. Terrisse saw no reason why the ordinary labourer should be refused the means by which to improve his situation.

Following this opening salvo, the debate intensified and culminated in the removal of the Jesuits from their colleges and their expulsion from France between 1762 and 1764 . The best remembered of the numerous tracts on education issued in France in these years was Rousseau's Emile, published in May 1762. Brown read this work soon after its appearance and found much to criticize in it. But the single-pupil and single-teacher premise of Rousseau's work ensured that it would have a limited impact on the question of organized education. More relevant was La Chalotais' ground-breaking Essai d'éducation nationale in 1763, which recieved a wide circulation, including Dutch (1770), Russian (1770), and German (1771) translations. ${ }^{22}$ La Chalotais achieved national fame for his part in the legal proceeding that led to the banishment of the Jesuits. According to the Essai, education should be shorn of its clerical associations and organised on a national basis. Its purpose was to prepare the children of the aristocracy and middle ranks to be effective and participating members of a modern society, and not, as was alleged of existing schools, 'as souls destined for an after-life or mere passive devotees of dead languages. ${ }^{23}$ Following Montesquieu, La Chalotais argued for a correlation between the principles of education and the laws of government. ${ }^{24}$ And, taking matters a short step further than Locke, he assumed an almost total plasticity of human nature and attributed social ills to wrong education. If the nature of men is fixed and determinate then education 
would be limited, but if they have no nature then the possibilities for education are infinite (Locke's 'nine parts of ten' is turned into 'ten parts of ten'). It followed that a properly ordered environment coupled with the right kind of schooling would produce a better and possibly a perfect society. Helvétius had much the same to say in the later De l'homme et de l'éducation (1772), in which he attacked the role of the Jesuits in education. But it was La Chalotais who first demanded for the French nation an education dependent upon the state alone: 'education belongs essentially to the State' because 'the teaching of morality belongs, and always has belonged, to the state. ${ }^{25}$ The conception of education as a public service quickly became a commonplace of French political thought. Nor were such ideas restricted to enlightened France: in Austria and in the states of Germany plans were also afoot to extend secular education under state control. ${ }^{26}$

England's experience was far different. Thomas Sheridan's essay on British Education (1756) went some way towards developing Montesquieu's thesis that the laws of education ought to be in relation to the principles of government. And Mary Wollstonecraft, at the end of the century, demanded the establishment of schools for public instruction supported by the state. ${ }^{27}$ But the bulk of opinion on the matter was decidedly against state interference in education. A healthy distrust of state enterprizes contributed to the longevity of the voluntary principle in England. It was against the grain, therefore, when Brown counselled the legislature to take a greater interest in education. Like La Chalotais, he ignored Montesquieu's warnings of the attraction of uniform schemes to small minds ${ }^{28}$ Nor could he accept Montesquieu's view that it is for legislation to conform to the spirit of the nation - its spirit may at any one time be corrupt. Rather, Brown agreed with Diderot that 'it is for legislation to mold the spirit of the nation. ${ }^{29}$ What he had in mind was 'a general and prescribed Improvement of the Laws of Education, ${ }^{30}$ in essence a restructuring of England's educational practices - and not only for the sons and daughters of the rich but also for the poorer ranks.

In extending his scheme to include the off-spring of labourers Brown was to go much further than his French contemporary. La Chalotais, like many others in France and England, feared that over-education would result in social disjunction. He found himself on the horns of a dilemma: on the one horn were the drawbacks associated with the ignorance of the labouring population, and on the other, there were the dangers that followed its education. ${ }^{31}$ Brown's solution to this conundrum was to fashion instruction such that the lower ranks would be induced to accept their place in the constituted order - a middleway between ignorance and over-education. In other words, he would minimize the dangers by limiting instruction within boundaries set by social and economic utility. 
That the dissenters Priestley and Godwin should find so much to resist in Brown's scheme is indicative of its narrow, authoritarian and political character. It was a scheme manifestly antithetical to the thought of those Englishmen (Whigs as well as radicals) anxious to broaden the parameters of civil and religious liberty in late eighteenth-century England.

In the three essays on 'The First Principles of Education' Brown offered a detailed discussion of the rules and objectives of a programme of early education. The major defect of past works on education, he argued, was that they neglected or opposed outright the practice of infusing a child's mind with precepts and rules which, he admitted, in the first instance must rely solely on the teacher's authority for acceptance. Moreover, educational theorists had not previously distinguished between the different Provinces of Habit and Reason, and consequently between the distinct Regulation of Passions and Opinions. ${ }^{32}$ These were the faults Brown was determined to rectify in the first of the essays. He also intended 'to obviate some Principles lately advanced by an Author of Reputation, which seems to have a Tendency unfavourable to Religion and Virtue. ${ }^{33}$ The author in question was Rousseau. After reading Emile, Brown paused to respond to some of its prescriptions. Probably his was the first English response to that justly famous treatise.

If Rousseau's was an open-ended scheme in which Emile was to be guided by a private tutor, only tackling things as and when his own nature dictated, Brown's was a narrowly conceived plan for controlled moral development from the earliest age to that point when children are capable of forming opinions for themselves, an age about which Brown was not specific. It is difficult to conceive of a plan of education quite so opposite to Rousseau's. In Rousseau's scheme the rules of education are predicated on the belief that freedom and not power is the greatest good, and that man is truly free when he desires only what he is able to perform and does what he desires. ${ }^{34}$ Brown could not fathom the worth of this seemingly anarchic approach. Similar to Locke's, his own plan dictated that the only sure method of early education is by the example of virtuous action and the inculcation of sound habits.

The influence of example was hardly a matter of debate. Even Rousseau showed his contempt for those educators who depended solely on spoken injunctions and prohibitions. As Lord Morley once remarked, Rousseau recognized 'the deeper language of example and the more living instruction of visible circumstance. ${ }^{.35}$ But Rousseau would not 
have agreed with Brown on the importance of forming habits early. Early habits, wrote Brown, 'generally determine our Practice through Life, and when once contracted and confirmed are seldom ever broken. ${ }^{36}$ It is imperative, therefore, that 'the natural liberty of the Mind . . . be checked, controuled, and thrown into a particular Direction. ${ }^{37}$ The stakes are high. Ultimately, if this is not done,

a very weak and imperfect State of Polity must arise; and in the End, a general Dissolution must insue [sic], through Want of that particular Direction of Habit and Principle which is the great bond of Social Union ... in which is concentered the Power of the agreeing Society; and without which, even the Strength of each Individual (wanting this common Direction and connecting Power) would indeed be the Weakness and destruction of the Whole. ${ }^{38}$

To ensure the duration of the virtuous state good citizens are required, and good citizens are formed by impressing upon them early habits which will fit them for society. A child should not be left to the follies of its own weak understanding to adopt fortuitously the maxims of corrupt times. Rather it should be 'conducted voluntarily' to adopt habits and principles 'consecrated by the approbation of the best and wisest of men,' and 'suitable to the Laws, the Customs, the Genius, of his own free Country.....'39

Brown's didacticism stands in striking contrast to Rousseau's radically individualist approach with its accent on the pupil's self-discovery of knowledge. But, in many respects, he was merely giving voice to the conventional wisdom against which Rousseau so eloquently protested. There are occasions, Brown argued, when a child must be treated on the mere principle of authority alone. At such times a parent's reason should stand in place of the child's. Nor is it necessarily the case, as Rousseau maintained, that caprice and tyranny will come to characterize the commands of the parent. To the end of maintaining the forms of freedom, Rousseau would leave the child to think he is master while you are really master. ${ }^{40}$ But this, replies Brown, takes no cognizance of the fact that the commands of parents are 'natural' and, though they may at times appear capricious, the continued acts of parental love and care which the child experiences will persuade him that their commands are well-intentioned. ${ }^{41}$ As for the system of 'natural correction' promoted by Rousseau - children were to be guided in morality by being suffered to incur the consequences of their own actions - Brown dismissed this as dangerously impractical. Rousseau, he writes, 'expects a Discernment of Consequences from a Child which we but seldom find in Men.' Experience may lead a child to provide for the future prevention of the 'immediate ill Consequences of his Actions,' but it could never direct him 
to provide for the avoidance of actions whose consequences were not immediate but ' which are more distant. ${ }^{42}$

Ultimately, Brown could not accept what Rousseau had made the bed-rock of his theory: the power of natural reason. According to Brown, this was 'one of the most common, and most dangerous Maxims in the Education of Children. ${ }^{43}$ Convinced, like Hume, that reason was the slave of the passions, he placed the onus on the development of sound habits: 'The Voice of the Passions is both louder, more intelligible, and more persuasive, than that of Reason. And the only Chance that Reason hath for Victory, is when the Passions are before-hand inlisted in her Service.' It is the task of reason to discern and choose the best means to obtain desired ends, but the universal motives to action are the 'Passions and pre-established Habits of Mankind. ${ }^{44}$ It is in this early formation of habits that the basic principles of Christian morality must be introduced. Reason must be given its 'proper Bias'; it must be thrown 'into the same great Channel with the universal Reason; that is, with the main Intention of the Creator, the general Good of All, the Nature and Constitution of Things. ${ }^{45}$

In the second and third of the essays 'On the First Principles of Education' Brown turned to a discussion of the best methods for inculcating the child with civic virtue. I do not have the space to go into detail here. Suffice it to say that of all the various parts of a child's instruction, religious beliefs are reserved for last on the grounds that they are best introduced when the rational faculties are sufficiently advanced (again, Brown was not specific as to age), when the mind is ready for 'higher Acquirements in Virtue.' By then the good habits and opinions already established in the mind of the child will provide a natural foundation on which to build true religion. ${ }^{46}$ According to Brown, a child in whom the basic principles of morality have already been instilled is in his heart already a Christian, and well prepared to receive the seed of religion. The strength virtue receives from religion will then inspire 'the growing Mind' with that unshakeable faith 'which naturally results from a just and extended view of God's moral Government. ${ }^{47}$ Naturally, the religion to be adopted was Protestant Christianity in its distinctly Anglican form. The Revolution Settlement of 1689 had confirmed England as a Protestant state; adherence to the state religion would guarantee public order and the maintenance of the government that presided over it. It was in this manner that Brown sought to bolster Anglicanism as the religion necessary to the survival of the Hanoverian state, to defeat Catholicism once and for all, and at the same time to deny the claims of dissent to full religious and political freedom.

In Brown's thoughts on early education, then, we can see that the tendency of all that he had to say was towards a scheme of moral 
development, such that by the time a child reached adulthood it would have thoroughly internalized the kind of habits and principles, secular and religious, which are most conducive to the observance of the laws and to the maintenance of the church and state as by law established.

III

In the new charity schools Brown believed he saw the best way for education in England to proceed on a national basis. He was not an uncritical supporter of these schools - there was still room for improvement - but he believed that they offered a unique opportunity for the state to intervene to infuse into the minds of England's young the principles and habits of Protestant virtue and civic obedience, freed from the drawbacks of parental influence. Brown, of course, was not particularly original in seeing the charity schools in this light. Indeed, in some respects it was Locke again who had showed the way. As early as 1693 Locke had advocated that working schools should be set up in every parish, with compulsory attendence for children between the ages of three and fourteen. Such schools, he thought, would act as a deterrent to pauperism, make the poor self-supporting, and accustom them early on to 'a civil and industrious course of life. ${ }^{48}$ Nevertheless, it was well into the following century before the idea was treated seriously. Even then, not everyone who supported the charity schools looked on them from quite the same perspective, and there were some forceful voices raised to condemn them altogether.

Sometimes termed English, or elementary, or free, or non-classical, or catechetical schools, the charity school movement really began with the founding of the Society for Promoting Christian Knowledge (SPCK) in 1698. ${ }^{49}$ The SPCK took the restoration of the nation's morals and religion as its primary goal. To this end it promoted a program of founding schools and the publication and distribution of suitable religious literature. The movement was parish-based and spread rapidly throughout the country. Special collections were held following the preaching of 'charity sermons' which proved to be extremely successful in raising the required funds. Returns from the SPCK indicate that in 1723 there were 1,329 schools instructing 23,421 pupils. ${ }^{50}$ By 1750 there were approximately 50,000 children receiving instruction in more than 2,000 schools connected with the SPCK. ${ }^{51}$ It was a movement which continued to grow throughout the century. According to Lord Brougham's estimates, by 1818 there were about 18,500 day schools in England and Wales at which 644,000 children received instruction. ${ }^{52}$ In some schools reading, writing and arithmetic were provided in addition to religious instruction. After 
the passing of the General Act of 1723 working schools on Locke's model began to appear, and their reputation for improving the moral character of the workers quickly spread.$^{53}$ But whatever the type of school or the curriculum taught, those schools connected with the SPCK were counselled to cultivate a proper spirit of loyalty in their pupils. To this end, reports were issued by the Society directing school trustees to give instruction to children in their duty to the House of Hanover, and reminding the schools that they were the bulwark and defence of the Reformation. Only after the Rebellion of 1745 when Jacobitism ceased to be a threat to the Protestant Succession, and the battles between religious and political factions for control of the charity schools lost their earlier rancor, were these directives gradually dropped from the reports. $^{54}$

Mandeville was one of the few who refused to see any worth in the charity school enterprize. He denigrated the practice of educating the children of the poor as wasteful and ultimately destructive of the end it was intended to achieve. In the essay On Charity and the Charity Schools (1723) he objected to the schools on three counts. First, those who promoted this policy were hypocrites who, far from acting out of Christian charity, were partisans - Whigs and Tories, dissenters and Anglicans - who vied with each other in the effort to indoctrinate the young in the beliefs and principles of their own party and thus to swell the number of their supporters. ${ }^{55}$ Second, the claim that the schools helped to keep down crime could not be proven and, in Mandeville's opinion, in fact they were likely to encourage criminal activities. A little knowledge, in other words, could prove to be a dangerous commodity. ${ }^{56} \mathrm{Third}$, it is a mistaken notion that religion is promoted through the acquisition of knowledge. Rather it is ignorance which is 'the Mother of Devotion,' as it is likewise of honesty. Knowledge, Mandeville shrewdly argued, breeds impiety. ${ }^{57}$

These criticisms, as speculative as they must be allowed to be, could hardly amount to sufficient reason to abandon the charity schools. But there was a more pressing question lurking behind Mandeville's critique: should the youthful poor be educated at all? Not according to Mandeville. The comforts of life depend upon the labouring ranks, without whom the social fabric would crumble. It is necessary that labourers be numerous and that they not be encouraged by education to attempt to advance themselves above their proper station..$^{58}$ No nation could be great in the world without a large supply of ignorant workers. By seeking to educate them the promoters of the charity schools threatened the structure of English society.

Mandeville's critique, naturally, was not allowed to go unanswered. ${ }^{59}$ Nevertheless, implicit in his antagonism was the perceptive recognition 
of the power of education to provide the stimulus for the overhaul or restructuring of societies. Philanthropists and reformers who supported the schools frequently did so on the grounds that the education of the poor would instill a feeling of gratitude in them toward their superiors, enable them to imbibe the Scriptures, to better earn a useful living, and thus to solidify existing social patterns. But what Mandeville realized and many after him came to hope would be the case - was that educating the lower orders was a recipe for discontent, which could give rise to a challenge to the very social order that the proponents of the charity schools had meant schooling the youthful poor to preserve. As one modern commentator has remarked, 'Working class literacy, which made working class politics possible, proved to be a potent weapon ... forged, almost unknowingly, throughout the eighteenth century . . . ${ }^{60}$

Brown supported the movement which Mandeville so disparaged and feared. He replied to Mandeville's critique in his published sermons 'On the Duty of Charitable Distribution.' Brown's discussion begins with the standard arguments from Christian duty. ${ }^{61}$ However, the real thrust of his defence of the schools was to point out the opportunity they afforded for impregnating the young with the tenets of rational Protestantism and civic obedience. In common with other reformers, Brown lamented the visible decay of religion in England and the increase in 'deism' and vice. He attributed these developments chiefly to ignorance and to the want of care in the education of the young. The children of the poor must be educated in good habits before vices become 'too strongly rooted, to be effectually removed either by our Munificence or our Instruction. ${ }^{62}$ They should not be left to imbibe corrupt maxims and manners but, as he had already written in the second of the essays on Shaftesbury's Characteristics, be happily conducted to embrace those religious Principles, which have had the Approbation of the best and wisest Men in every Age and Nation; and which are known and allowed to be the only Means of true Happiness to Individuals, Families, and States. ${ }^{63}$

Brown, however, was not an uncritical advocate of the charity schools. He believed that improvements could still be made. For example, he thought that something more could be done by the schools to rescue children from the ill-example and influence of parents. He suggested that a system might be set up whereby the morals of parents could be inspected, but he offered few details as to how this could be made to work. ${ }^{64} \mathrm{He}$ also thought the curriculum of some of the schools to be too advanced. In this respect Brown had taken Mandeville's critique to heart and he warned that the schools should be wary of over-educating the poor. Further than enabling them to absorb the truths of the Bible, he pointedly cautioned that 'a Smattering in Knowl- 
edge puffeth up instead of edifying. ${ }^{65}$ Finally, Brown argued that the schools should pay more attention to industry, because this is 'a Part of every poor Man's Virtue' and 'this Duty can never be sustained without an early Habit of Industry. ${ }^{66}$ So important was this consideration to Brown - and, indeed, to the declared policy of preserving the order of society intact - that he went so far as to state it as the primary aim of the charity schools. They were to create an early and lasting impression in the minds of the youthful poor 'of their being destined to a life of continued Industry. ${ }^{67}$

From the essays 'On the First Principles of Education' and the sermons 'On the Duty of Charitable Distribution' we can glean some idea of the direction of Brown's thoughts concerning a code of national education. So far as was possible he would segregate children from parents; he would employ supervisors of morality to diminish the adverse influence of parents when contact was unavoidable; and in suitable institutions he would instill into the minds of the young the fundamental articles of rational Protestantism, instruct them in the basic tenets of morality, and inculcate the necessity of discipline and industry. By such methods Brown would have the labouring poor content with their lot and the existing social arrangements made secure.

Before moving on we should perhaps pause to say a few words about Brown's views on female education, contained in a sermon delivered on 16 May 1765 before the guardians of the charity school of the Asylum for Deserted Female Orphans. ${ }^{68}$ Not surprisingly, given the age, the attentions of educationalists were focused almost exclusively on male education; Brown was one of the few who saw the need to reflect upon the correct schooling for those of the opposite sex. Nonetheless, his thoughts reached no further than the commonplace. Because a child's first teacher is usually the mother or nurse, the education of women assumed its importance. If that education were to be deficient, this would work to the detriment of the child. What revelations on the correct female education does Brown have? It should be suited to the traditional place of women as the support of their husbands and nurse to their children. For this they require not education per se, but guidance in the development of their character. Like Rousseau's education for Sophie - destined to be the chief support for Emile - Brown's idea of female education is not an ideal. Rather it is a literal statement of what eighteenth-century society thought sufficient for the proper up-bringing of young girls. 
That the legislature should take a greater interest in education was the conclusion reached by Brown in his last major political work, Thoughts on Civil Liberty, On Licentiousness and Faction (1765). The difficulties of a government reforming the nation's manners and principles he knew to be immense: 'the perfect cure will require the attention and labour of an age,' he once wrote. ${ }^{69}$ Even so the means to 'this great work' were to hand:

A pure and rational Religion; a generous System of Policy, founded on that Religion; Manners, tho' apparently degenerate, yet by no Means generally profligate; much true Religion, Integrity, and Honour among the middle Ranks; many Instances of domestic Worth among the higher; and in spite of the Temptations that surround the Great, true Piety, and the moral Virtues adorning the most exalted Station. ${ }^{70}$

Evident here is a softening of the stance taken by Brown in the Estimate, but the earlier work had an essentially critical intent. In contrast, Thoughts on Civil Liberty was intended to do for England what La Chalotais' Essai purported to do for France: to lay the ground for a rejuvenation of the national character.

In Thoughts on Civil Liberty, as a preliminary to his observations on the faults of English institutions, Brown set out a lengthy comparative analysis of the manners and political arrangements of the Spartans, Athenians, and Romans. By pin-pointing their various strengths and weaknesses he intended to bring the political and social problems of eighteenth-century England into sharp relief. Compared to those of Athens and Rome, the institutions of Sparta, Brown thought, to be barbaric (they promoted prostitution, adultery, thieving, and condoned assassination), but what he admired was the way these institutions were preserved over such a long period of time. The harmony of Sparta's institutions, together with the promotion of austere principles, secured the long duration of her government. This was the great success of Lycurgus. ${ }^{71}$ Sparta was the perfect example of a state in which the coincidence of passions and desires with public law was achieved. In Sparta the institutions were supreme, regulating every mode of human action. Not only were the principles of religion, honour and civic virtue harnessed to this task, but the unified system of education created the spirit of patriotism so necessary to a free state. ${ }^{72}$ Thus were the Spartans, writes Brown, 'strongly and unalterably possessed with the Love of their Country. ${ }^{73}$ 
Like Athens and Rome, England lacked Sparta's 'Self-Consistence, and perfect Unity of Parts. ${ }^{74}$ This was the consequence of two related problems. First, the institutions of England had not been fashioned by an English Lycurgus; rather they were the result of 'the fortuitous Events of Time. ${ }^{, 75}$ There was little that immediately could be done to remedy this state of affairs. Second, England's political structure was not supported by a related code of education. It remained in the power of parents to educate their children in the manner they saw fit, whether it be coupled with a reverence for the English system of polity and religion or directed against it. ${ }^{76}$ This was where a start could be made to set England's institutions on their correct foundation. Children must be taught early to disdain the degenerate manners and principles currently in vogue. They must be instilled with virtue, with the habits and opinions which concur with the maintenance of a free, Hanoverian and Protestant Christian state. To shape the charity schools to that end was the opportunity Brown saw. In these schools large numbers of England's youthful poor could be taught to embrace and respect the existing social and political order. Here subservient subjects could be formed who, through their industry, Protestant faith and sense of civic virtue, could be expected to contribute unsparingly to the well-being of the state.

There were strong objections made to both the expediency and the practicality of instituting the scheme Brown proposed. The radical dissenter Joseph Priestley met Brown with a direct negative: the reasons why Brown wanted to see a system of national education imposed were precisely the reasons why it should not. It was a scheme designed to fortify the existing aristocratic and intolerant arrangements of social and political life. Children were to be instilled with habits and opinions with no other purpose in mind than the maintenance of church and state as by law established. Such a scheme Priestley deemed a violation of individual rights, anathema to the proper end of education, incompatible with the ends of civil society and, in effect, a formula for servitude and national stagnation and a reneging on the settlement of $1689 .{ }^{77}$ The advantages of education, he argued, are more effectually secured when it is conducted by personally involved and interested individuals of many sorts than when it is controlled by government directives.

It was the schemes for national education proposed by French revolutionaries, inspired by the ideas of La Chalotais and others, that prompted another radical dissenter, William Godwin, to remark that it was their very political nature which demanded that they be rejected. 'The project of national education,' he wrote, 'ought uniformly to be discouraged, on account of its obvious alliance with national government. ${ }^{78}$ Godwin feared, like Priestley, that an education system under the control of the government, whether in England or France, would be 
used to strengthen its position and to perpetuate existing social and political arrangements. The young, Godwin announced, ought not to be taught to venerate the constitution but to venerate truth, and the constitution only in so far as it corresponded with 'their uninfluenced deductions of truth.' Schemes of national education tend to perpetuate errors and 'to form all minds upon one model. ${ }^{.79}$

Brown took the example of Sparta to extraordinary lengths in his plans for reform of Russia under Catherine the Great. ${ }^{80}$ Catherine had been engaged in the task of revising Russia's criminal code for some years, culminating in her 'Instruction.' Issued in 1767, this was intended to serve as the basis for a new civil and criminal code. ${ }^{81}$ Initially, Brown's advice had been solicited as a part of the Czarina's efforts to improve the state of education in Russia. His zeal for reform went much further than most and he was invited to attend Catherine's court to play a role in her broader scheme to tackle the Russian legal system. The last months before his suicide in 1766 were entirely consumed by the project. Indeed, it may well have hastened his demise.

In the correspondence from Brown to the Czarina and her envoys the fundamental features of his views on national education are reiterated in attenuated form. He placed great emphasis on the power which is in the hands of government (in this case the unlimited sovereignty of Catherine) and its duty to set the institutions of state to producing virtuous and patriotic citizens. He made much of the supreme importance of religious principles in the process of education (in this case those of the Greek Orthodox Church). Finally, he advocated an early education isolated from the influence of parents. But Brown went further to set on foot a scheme, entirely impractical, for the civilization of a Russian state of which he knew very little and was wont to see as barbaric. ${ }^{82}$ Often prone to delusions of grandeur (and to fits of melancholy), he fancied that England's own salvation might best be served if he were with Catherine to guide her hand. As he put it to a friend,

I can fancy that I see civilization and a rational system of Christianity extending themselves quite across the immense continent, from Petersburg to Kamschatska. - I can fancy that I see them striking farther into the more southern regions of Tartary and China, and spreading their influence even over the nations of Europe; which though now polished, are far from being truly Christian or truly happy. Nay, I am sometimes fantastic enough to say with Pitt, that as America was conquered in Germany, so Great Britain may be reformed in Russia. ${ }^{83}$ 
The episode ended in ridicule, with Brown publicly castigated by the poet William Mason in the St. James Chronicle, as a great reformer foiled by 'a Daemon, call'd the Gout' from making the trip to Russia which would establish his reputation as the modern day Lycurgus. ${ }^{84}$ It has been said that the thought of all London laughing at him was a contributing factor in Brown's suicide, which occurred less than a month after the publication of Mason's poem. ${ }^{85}$ There is no evidence that Brown had seen the offending ode, but since he was then residing in London it is probable that it was brought to his attention. Mason himself, who seems to have borne ill-feeling toward Brown for some time, ${ }^{86}$ was afraid that his satire had forced Brown over the edge. Thomas Gray did his best to allay Mason's fears, ${ }^{87}$ but there can be no doubt that the proposed trip to Russia was a rash and ill-considered scheme guaranteed to give rise to a certain amount of levity amongst the metropolitan literati.

Perhaps all we can say in Brown's defence is that he was not alone in his admiration for the Empress or in holding the belief that great things could be accomplished by the power she possessed. One need only look at the correspondence between Voltaire and Catherine to realize the fawning belief in her power and will to achieve magnificent heights that he, Europe's leading man of letters, occasionally uttered. And, did not Diderot, only a few years later, make the trip that Brown was prevented from making, and thence proceed to act upon just such a principle as he himself had proposed: 'the unlimited sovereignty and power of her Imperial Majesty' ${ }^{88}$ Nor was it long after that that Jeremy Bentham set out to join his brother Samuel in Russia with the stated objective of influencing Catherine in her efforts to codify the laws of Russia. Neither the Frenchmen nor the Englishmen had much success with the Empress. ${ }^{89}$ But complicity in error is really no defence at all. At least Diderot had the excuse that he was financially indebted to Catherine for purchasing his library. ${ }^{90}$

\section{VI}

According to Brown, then, the aim of education was to indoctrinate children with those social and moral 'truths' which would enable them in later adult life to grasp and pursue their real or long-term interests. But his underlying postulate is that the individual's interest is intimately bound up with the interests of the state. The end of education is, therefore, elitist and political. Brown saw its purpose as fashioning citizens who would naturally subordinate their private interests to the good of the state, and it was necessary that the state intervene to ensure this outcome. England's youth should be shielded from corrupt man- 
ners and uniformly educated in opinions and habits based on the precepts of the established religion and the political principles of the Revolution Settlement.

In developing this scheme of national education Brown was in part reacting to the debates, fostered by the ideas of Locke, which occupied educationalists in England in the first half of the eighteenth century. To a significant degree he was also responding to French writers and importing French ideas into England. Not that he accepted all that the philosophes advocated. ${ }^{91}$ He opposed outright Rousseau's progamme for individualist instruction, and would never have agreed to La Chalotais' suggestion that education should be shorn of its religious associations. Nevertheless, on the issue of state intervention Brown found himself very much in tune with prevailing French sentiment, and in this regard laid down important debating points for those involved in the 'Schools for All' controversy, which burst upon England in the first two decades of the following century.

\section{JAMES E. CRIMMINS}

Huron College, University of Western Ontario

\section{Notes}

* I wish to thank Professor Roger L. Emerson of the University of Western Ontario for his many helpful comments, and the anonymous referee of this journal who suggested some additional improvements.

1 Garrick acted in Brown's plays - Barbarossa, at Drury Lane in 1754, and Athelstane, at Covent Garden in 1756 - writing the prologue for the first and epilogues for both. 'It being mentioned, that Garrick assisted Dr. Browne (sic) ... in some dramatic composition, 'No sir', said Johnson, 'he would no more suffer Garrick to write a line in his play, than he would suffer him to mount his pulpit'.' Boswell's Life of Johnson, ed. J.W. Croker (London, 1890), p. 220.

2 A.W. Evans, Warburton and the Warburtonians (London: OUP, 1932), p. 199.

3 See ibid, pp. 199-200; and Warburton to Hurd (23 December 1750), Richard Hurd, Letters from an Eminent Prelate to One of his Friends, 2nd ed. (London: 1809), Letter XXXII, p. 71.

4 J.S. Mill, 'Bentham' (1838), in Collected Works of John Stuart Mill, vol. X, ed. J.M. Robson (Toronto: $U$ of Toronto P, 1969), pp. 86-87.

5 John Brown, An Estimate of the Manners and Principles of the Times, 2 vols. (London: 1757, 1758), I, 191, 29. 
6 For bibliographic details of this and Brown's other writings, see Donald D. Eddy, A Bibliography of John Brown (New York: Bibliographical Society of America, 1971).

7 The second volume of the Estimate, published the following year, was much less successful and exposed Brown to a good deal of censure. See, for example, Some Doubts Occasioned by the Second Volume of an Estimate ... (London: 1758); Friendly Admonitions to the Inhabitants of Great Britain . . . by 'Britannicus' (London: 1758); Annual Register, vol. I (1959), p. 445; Letters to the Estimator of the Manners and Principles of the Times ... by 'Swithin Swing' (London: 1758); [James Ralph], The Case of Authors by Profession or Trade, Stated . . (London: 1758); and John Gordon, A New Estimate of the Manners and Principles ... (Cambridge: 1760). Brown replied to his critics in An Explanatory Defence of the Estimate of the Manners and Principles of the Times (London: 1758).

8 Horace Walpole's Correspondence, ed. W.S. Lewis and others (London: OUP, 1937-80), II, 187.

9 See my "The Study of True Politics': John Brown on Manners and Liberty,' Studies on Voltaire and the Eighteenth Century, vol. 241 (1986), 65-86. I have also given attention to Brown's moral thought in 'John Brown and the Theological Tradition of Utilitarian Ethics,' History of Political Thought, vol. 4 (1983), 523-50.

10 The most notable exception is Brown's conjectural history of poetry and music, which shows some similiarities to the work of Vico in this area. John Brown, $A$ Dissertation on the Rise, Union, and Power, The Progressions, Separations, and Corruptions, Of Poetry and Music (London: 1763); later reissued in abbreviated form as The History of the Rise and Progress of Poetry, through its Several Species (Newcastle: 1764).

11 The essays and sermons are to be found in John Brown, Sermons on Several Subjects (London: 1765).

12 The major letters concerning Russian reform are reproduced in Andrew Kippis, Biographia Britannica (London: 1780), II, 664-72; for a commentary on these see the appendix to my unpublished M.A. thesis 'The Political Ideas of the Rev. Dr. John Brown (1715-66),' University College of Swansea, 1980.

13 For the connection with Plutarch I am indebted to J.A. Passmore, 'The Malleability of Man in Eighteenth-Century Thought,' in Earl R. Wasserman, Aspects of the Eighteenth Century (Baltimore: Johns Hopkins Press, 1965), p. 25.

14 John Locke, Some Thoughts Concerning Education (1693), in The Works of John Locke, 10th ed. (London: 1801), IX, secs. 4-5.

15 Passmore, 'The Malleability of Man in Eighteenth-Century Thought,' p. 25.

16 Locke, Some Thoughts Concerning Education, sec. 1.

17 Ibid., sec. 70.

18 Brown, Estimate, I, 30-31. See John Clarke, An Essay upon the Education of Youth in Grammar Schools, 2nd ed. (London: 1730), pp. 8-9. For the views of Comenius see Robert R. Rusk, The Doctrines of the Great Educators, 4th ed. (New York: Macmillan, 1969), Ch.V.

19 Brown, Estimate, I, 34-35; Adam Smith, The Wealth of Nations, 2 vols. (London: J. M. Dent \& Sons, 1910), II, Bk.V, Part III, Art. ii, p. 257. Locke held that the common practice of sending sixteen to twenty-one year old youths abroad was misguided. 
He considered that it should be allowed only to those who had reached an age when they could be discriminating in their judgement (presumably sometime after the age of twenty-one). Locke, Some Thoughts Concerning Education, sec. 211.

20 Brown, Estimate, II, 70.

21 A shortened version of the Examen was published in the Précis analytique des Travaux de l'Académie des Sciences, Belles-Lettres et Arts de Rouen, 1744-50 (Rouen: 1814). For a discussion see Harvey Chisick, The Limits of Reform in the Enlightenment: Attitudes toward the Education of the Lower Classes in Eighteenth-Century France (Princeton, New Jersey: Princeton UP, 1981), pp. 78-89, and for the ensuing debate see Ch.II, passim.

22 Chisick, The Limits of Reform in the Enlightenment, pp. 89-90. For a discussion of La Chalotais' Essai see pp. 89-104 of this work.

23 The School of the French Revolution. A documentary history of The College of Louisle-Grand and its director, Jean-François Champagne 1762-1814, ed. and trans. by R.R. Palmer (Princeton, New Jersey: Princeton UP, 1975), p. 23.

24 Baron de Montesquieu, De l'esprit des lois (1748), trans. Thomas Nugent as The Spirit of the Laws (1750), 2 vols (New York: Haafner, 1949), I, Bk.IV.

25 L.R.C. de La Chalotais, Essai d'éducation nationale, ou Plan d'études pour la jeunesse (Paris, 1763), quoted by Passmore, 'The Malleability of Man in Eighteenth-Century Thought', p. 44.

26 M.G. Jones, The Charity School Movement. A Study of Eighteenth-Century Puritanism in Action (Hamden, Connecticut: Archon Books, 1964), p. 339.

27 Thomas Sheridan, British Education, or the Source of the Disorders of Great Britain (London: 1756); Mary Wollstonecraft, A Vindication of the Rights of Woman (London: 1792).

28 See Montesquieu, Spirit of the Laws, II, Bk. XXIX, Ch.18, pp.169-70.

29 D. Diderot, Observations on the Drawing Up of Laws (1774), in Diderot's Selected Writings, ed. L.G. Crocker (New York: Macmillan, 1966), p. 304.

30 John Brown, Thoughts on Civil Liberty, On Licentiousness and Faction (Newcastle upon Tyne: 1765), p. 156.

31 Chisick, The Limits of Reform in the Enlightenment, p. 119.

32 Brown, 'On the First Principles of Education', I, in Sermons, pp. 5-6.

33 Ibid., p. 6.

34 Jean-Jacques Rousseau, Emile, trans. Barbara Foxley (London: J. M. Dent \& Sons, 1914), p. 48.

35 Lord Morley quoted by Ernest Rhys, in Rousseau, Emile, introduction, p. viii; and Brown, 'On the First Principles of Education,' I, Sermons, pp. 10-11.

36 Brown, 'On the the First Principles of Education,' I, Sermons, p. 8.

37 Ibid., p. 15.

38 Ibid., p. 16.

39 Brown, Thoughts on Civil Liberty, p. 41.

40 Rousseau, Emile, p. 84. 
41 Brown, 'On the First Principles of Education,' I, Sermons, pp. 19-20.

42 Ibid., pp. 21-22.

43 Ibid., p. 23.

44 Ibid., p. 25; see also Brown, Thoughts on Civil Liberty, p. 40.

45 Brown, 'On the First Principles of Education,' I, Sermons, p. 27.

46 Ibid., III, Sermons, pp. 61-62 (incorrectly numbered 57 and 58).

47 Ibid., p. 63 (incorrectly numbered 59).

48 Jones, The Charity School Movement, p. 31.

49 Ibid., pp. 20-21, 23.

50 Ibid., p. 24.

51 Ivor Morrish, Education Since 1800 (London: Allen \& Unwin, 1970), pp. 4-5. The incomplete character of the returns of the SPCK make such estimates uncertain; nor do these figures take account of those schools which had ceased to exist by 1750 .

52 Jones, Charity School Movement, p. 27.

53 Ibid., p. 88.

54 Ibid., pp. 129-30, and Ch.IV, passim.

55 Bernard Mandeville, On Charity and the Charity Schools, in The Fable of the Bees; or Private Vices, Public Benefits, 2 vols, ed. F.B. Kaye (Oxford: Clarendon, 1924, rpt. 1957), I, 354.

56 Ibid., p. 308.

57 Ibid., p. 304.

58 Ibid., pp. 345-46, 328, 369.

59 One of the most comprehensive replies to Mandeville came from the hand of Samuel Parr later in the century. A Discourse on Education and on the Plans pursued in the Charity Schools (London: 1786).

60 Victor E. Neuburg, Popular Education in Eighteenth-Century England (London: Woburn Press, 1971), p. 151.

61 Brown, 'On the Duty of Charitable Distribution,' II, Sermons, p. 159.

62 Ibid.

63 John Brown, Essays on the Characteristics of the Earl of Shaftesbury, 3rd ed. (London: 1752), p. 234.

64 Brown, 'On the Duty of Charitable Distribution,' II, Sermons, p. 163.

65 Ibid., p. 164.

66 Ibid., pp. 164-65.

67 Ibid., p. 166.

68 John Brown, Of the Female Character and Education: A Sermon Preached on Thursday the 16th of May, 1765, At the Anniversary Meeting of the Guardians of the Asylum for Deserted Female Orphans (London: 1765). 
69 Brown, Explanatory Defence of the Estimate, p. 84.

70 Brown, Thoughts on Civil Liberty, pp. 158-59.

71 For the role played by the myth of Sparta in eighteenth-century thought see Elizabeth Strawson, The Spartan Tradition in European Thought (Oxford: Clarendon, 1969).

72 Brown, Thoughts on Civil Liberty, pp. 49-50.

73 Ibid, p. 47.

74 Ibid., pp. 81-82.

75 Ibid.

76 Ibid., pp. 84.

77 Joseph Priestley, An Essay on the First Principles of Government, and on the Nature of Political, Civil and Religious Liberty (1768), 2nd ed. (London: 1771), pp. 84-108. In the preface Priestley announced that this work 'owes its rise to the remarks I formerly wrote on Dr Brown's proposal for a code of Education', a reference to Priestley's Remarks on a Code of Education Proposed by Dr Brown, which was printed with An Essay on a Course of Liberal Education (London: 1765). I have not seen a copy of the Remarks, but Priestley assures us that its substance is repeated in a more concise form in the Essay on the First Principles of Government.

78 William Godwin, Enquiry concerning Political Justice and its Influence on Morals and Happiness (1798), ed. Isaac Kramnick (Harmondsworth: Penguin, 1976), p. 616.

79 Ibid., p. 617.

80 These plans are discussed briefly by Nicholas Hans, 'Dumaresq, Brown and Some Early Educational Projects of Catherine II', The Slavonic and East European Review, vol. 40 (1961-62), 229-35.

81 Leon Radcinowicz, A History of English Criminal Law and its Administration from 1750, 3 vols. (London: Stevens \& Sons), I, 296.

82 See the letters in Kippis, Biographia Britannica, II, 664-66, 669-72.

83 Ibid., pp. 666-67 note.

84 William Mason, 'Extract from an Ode to the Legislator Elect of Russia on his being prevented from entering on his high Office of Civilization by a Fit of the Gout', published anonymously in the 'Poets Corner' of the St. James Chronicle, 26-28 August, 1766, and reproduced in The Correspondence of Thomas Gray, ed. Paget Toynbee and Leonard Whibley, 3 vols (Oxford: Clarendon, 1935), III, Appendix R.

85 P.M. Horsley, 'Dr. John Brown (1715-1766)', Transactions of the Cumberland and Westmorland Antiquarian and Archaelogical Society, New Series, vol. 69 (1969), $270-71$.

86 Thomas Gray refers to 'your Enemy, Dr. Brown' in a letter to Mason (7 Sep. 1757), and Warburton also hinted at the dislike between the two in a letter to Richard Hurd (19 Feb. 1760). See The Correspondence of Thomas Gray, II, Letter 248, pp. 523, 524 note.

87 There are three letters from Gray to Mason which touch on the matter. See The Correspondence of Thomas Gray, III, Letters 423, 427, 428, pp. 933-34, 938-40.

88 See Brown to Dr. Dumaresq (Oct. 1, 1765), Kippis, Biographia Britannica, II, 664. 
89 See The Correspondence of Jeremy Bentham, vol. 3, ed. Ian R. Christie (London: Athlone Press, 1971), passim.

90 Carol Blum, Diderot. The Virtue of a Philosopher (New York: Viking Press, 1974), p. 109.

91 For Brown's affinity with the French philosophes, see my "The Study of True Politics': John Brown on Manners and Liberty,' pp. 84-85. 